\title{
Fair trade phenomenon and its evolution in Visegrad countries
}

\author{
Wojciech Zysk
}

\begin{tabular}{|c|c|}
\hline \multicolumn{2}{|r|}{ A B S T R ACT } \\
\hline \multicolumn{2}{|c|}{$\begin{array}{l}\text { Objective: The objectives of this paper are as follows: to describe how the Fair Trade } \\
\text { movement supports the achievement of the Sustainable Development Goals (SDGs), } \\
\text { also using A Theory of Change, to analyze the Trade Fair phenomenon in the global } \\
\text { scale, in the V4 countries and make a comparison with selected EU countries as well } \\
\text { as an attempt to develop recommendations for the Visegrad Group countries in } \\
\text { terms of the Fair Trade development. }\end{array}$} \\
\hline \multicolumn{2}{|c|}{$\begin{array}{l}\text { Research Design \& Methods: The research methods applied in the article are: studying } \\
\text { the literature of the subject, analysis of source texts, the descriptive method and de- } \\
\text { ductive reasoning (the observational method combined with a case study). }\end{array}$} \\
\hline \multicolumn{2}{|c|}{$\begin{array}{l}\text { Findings: Fair Trade development level and the sales level in the analysed countries } \\
\text { considerably differ from other developed EU countries. }\end{array}$} \\
\hline \multicolumn{2}{|c|}{$\begin{array}{l}\text { Contribution } \& \text { Value Added: Therefore, it was proposed in the recommendations to } \\
\text { use the UK benchmarks and take advantage of the economic potential of the V4 group. }\end{array}$} \\
\hline Article type: & research paper \\
\hline Keywords: & $\begin{array}{l}\text { Fair Trade; Visegrad Group; Sustainable Development Goals; Theory } \\
\text { of Change; the poor South }\end{array}$ \\
\hline JEL codes: & P45, M14, F23, P33 \\
\hline Article $r$ & Article accepted: 11 December 2020 \\
\hline
\end{tabular}

\section{Suggested citation:}

Zysk, W. (2020). Fair trade phenomenon and its evolution in Visegrad countries. International Entrepreneurship Review (previously published as International Entrepreneurship / Przedsiębiorczość Międzynarodowa), 6(4), 81-98. https://doi.org/10.15678/IER.2020.0604.06

\section{INTRODUCTION}

Under the current level of internationalization and globalization some disturbing sociocultural, demographic and civilization phenomena, including the allocation of the population of the globe in terms of income and living standards, can be observed in the world. In September 2015, the United Nations General Assembly adopted a set of 17 overarching global goals to combat poverty and achieve sustainable development by 2030 . They were called the Sustainable Development Goals (SDGs). 
Covering topics from gender equality to climate change, and education to clean drinking water, they represent a powerful opportunity to improve the lives of 1.3 billion small scale farmers and agricultural workers upon whom the world depends to produce our food and protect our planet (United Nations, 2020). This is an urgent call for action by all countries - both the developed and the developing - in a global partnership. Many international organizations and programs support the implementation of these ambitious goals. The goals merely provide a framework. It is up to governments, but also businesses and civil societies, to take action in order to ensure they are achieved.

Fair Trade ${ }^{1}$ is one of the movements supporting the implementation of SDGs. How does Fair Trade contribute to the SDGs? There is a large amount of cross-over between the SDGs and Fair Trade's work. In fact, of the 169 targets underlying the goals, there is barely a single one that is not somehow related to food and farming. This means that smallholder farmers and workers have a central role to play (Fairtrade International, 2020a). Fair Trade has a direct and indirect impact on all 17 goals. A theory called A Theory of Change was also created. It describes the change that an initiative wishes to see in the world and its understanding of how it will contribute to that change. Fairtrade International has developed a Theory of Change for Fairtrade as a part of work to improve the Fairtrade Monitoring, Evaluation and Learning - MEL system.

Not only the richest countries in the world, but also the countries of our part of Europe should participate in the implementation of SDGs' goals. Moreover, it poses a challenge for the Visegrad Group countries (V4), characterized by a high standard of living of the population, high position in economic rankings - for example with regard to GDP, and Human Development Index - HDI. The Fair Trade phenomenon has also been developing in the V4 countries for several years. In the face of the processes mentioned above, ideas of responsibility and justice occur more and more often, particularly in the international context.

The objectives of this paper are as follows: to describe how the Fair Trade movement supports the achievement of The Sustainable Development Goals - SDGs, also using A Theory of Change, to analyze the Trade Fair phenomenon in the global scale, in the V4 countries and make a comparison with selected EU countries as well as an attempt to develop recommendations for the Visegrad Group countries in terms of the development of Fair Trade.

In the first part of the article there is a synthetic summary of the selected studies results focused on Fair Trade, then material and methods that were used, in the next section description of the relationship between Fair Trade and The Sustainable Development Goals. Then we can find Fair Trade product trading worldwide analysis, Fair Trade product trading in the V4 countries (very difficult to find data) and finally - very important section - recommendations for the V4 countries with regard to the development of Fair Trade.

\section{LITERATURE REVIEW}

The world literature presents numerous studies on Fair Trade. Since the global financial crisis of 2007-2009, the subject of Fair Trade - and even Fair Trade tourism - has increase-

\footnotetext{
${ }^{1}$ The terms Fairtrade, Fair Trade and others often appear in the literature. "Fairtrade" - defines the product certification system owned by Fairtrade International. "Fair Trade" - this concept is broader in meaning than "Fairtrade" and refers to the entire Fair Trade movement, including individual organizations and product certification systems. The last term will be used in the article.
} 
ingly appeared in the economic discourse. Analyzing the amount of scientific articles using a popular search engines we can observe that the issue of Fair Trade is, interestingly enough, relatively more and more frequently found in published economic literature. For example, when the Google Scholar - a well-known site of the scientific world - search engine was used, after entering the term "fair trade ${ }^{2 \prime} 27,300$ search results in years 1989-2008 (20 years) were found, while in the period 2009-2020 (only 12 years) as many as 37,700 . In the year 2020 alone (three months between January and March) we had 2,050 articles or books.

Table 1 shows examples of a synthetic summary of the selected studies results focused on Fair Trade, the articles analyzed below cover the post-crisis period. In the table below we can find subjects and short conclusions of reviewed publications.

Table 1. Summary of some research results focused on Fair Trade

\begin{tabular}{|c|c|c|}
\hline Reference & Subject & Conclusions \\
\hline $\begin{array}{l}\text { Aude- } \\
\text { brand\&Pauchant } \\
\text { 2009, 343-353 }\end{array}$ & $\begin{array}{l}\text { Can the fair trade move- } \\
\text { ment enrich traditional } \\
\text { business ethics? A histori- } \\
\text { cal study in Mexico }\end{array}$ & $\begin{array}{c}\text { Historical study of fair trade movement focuses on } \\
\text { the originalities and challenges of the FT movement } \\
\text { and its contributions to the current theory and } \\
\text { practice in business ethics. }\end{array}$ \\
\hline $\begin{array}{l}\text { Bezençon\&Blili } \\
2009,95-113\end{array}$ & $\begin{array}{l}\text { Fair trade managerial } \\
\text { practices: strategy, organ- } \\
\text { ization and engagement }\end{array}$ & $\begin{array}{l}\text { The motivations of distributors of fair trade prod- } \\
\text { ucts and how they organize and communicate fair } \\
\text { trade values (strategies, managerial practices, dis- } \\
\text { tribution). }\end{array}$ \\
\hline $\begin{array}{c}\text { Doran } 2009,549- \\
563\end{array}$ & $\begin{array}{l}\text { Research in the U.S. on } \\
\text { Fair Trade consumption }\end{array}$ & $\begin{array}{c}\text { There are significant interactions between personal } \\
\text { values and fair trade consumption and that de- } \\
\text { mographics proved to be useless in creating a pro- } \\
\text { file of the American Fair Trade consumer }\end{array}$ \\
\hline $\begin{array}{l}\text { Jaffee \& Howard } \\
\text { 2010, 387-399 }\end{array}$ & $\begin{array}{l}\text { Corporate cooptation of } \\
\text { organic and Fair Trade } \\
\text { standards }\end{array}$ & $\begin{array}{l}\text { Corporate firms have deployed to further capital } \\
\text { accumulation and to defuse threats to their profit } \\
\text { margins and to status quo production, pricing, la- } \\
\text { bor, trading and retailing practices. }\end{array}$ \\
\hline $\begin{array}{l}\text { Nicholls 2010, } \\
\text { 241-255 }\end{array}$ & $\begin{array}{l}\text { Fair Trade as a form of so- } \\
\text { cial entrepreneurship }\end{array}$ & $\begin{array}{c}\text { A neo- institutionalist perspective to analyse Fair } \\
\text { Trade not simply as a new exchange model working } \\
\text { within existing organisational and economic struc- } \\
\text { tures, but rather as an agent of institutional entre- } \\
\text { preneurship. }\end{array}$ \\
\hline $\begin{array}{l}\text { Wilson 2010, } \\
\quad 84-92\end{array}$ & $\begin{array}{l}\text { Long-term indebtedness, } \\
\text { rising production costs in } \\
\text { Nicaragua }\end{array}$ & $\begin{array}{c}\text { Effort to raise the Fair Trade minimum price and } \\
\text { premium for coffee through Fair Trade Labelling Or- } \\
\text { ganizations International (FLO) in } 2008 \text { demon- } \\
\text { strated a good first step toward improving farm- } \\
\text { gate prices. }\end{array}$ \\
\hline $\begin{array}{l}\text { Goworek 2011, } \\
\quad 74-86\end{array}$ & $\begin{array}{l}\text { Literature on ethical fash- } \\
\text { ion companies }\end{array}$ & $\begin{array}{l}\text { Description of a significant trend for retailers to of- } \\
\text { fer ethical clothing ranges made from organic cot- } \\
\text { ton or produced by Fair Trade manufacturers. }\end{array}$ \\
\hline $\begin{array}{l}\text { Bondy\& Talwar } \\
2011,365-383\end{array}$ & $\begin{array}{l}\text { Fair Trade consumers } v \text {. } \\
\text { global economic recession }\end{array}$ & $\begin{array}{l}\text { The results reveal a discrepancy among fair trade } \\
\text { consumers in Canada, US and UK. }\end{array}$ \\
\hline
\end{tabular}

\footnotetext{
${ }^{2}$ Quotation marks were used in the search. For example: searching for 'wojciech profit' will give us results as if we combined the words 'wojciech' and 'profit' with the logical conjunction OR. A query "wojciech profit" (quotation marks) will give us only those results that contain the string "wojciech profit" in any part of the article or metadata.
} 


\begin{tabular}{|c|c|c|}
\hline Reference & Subject & Conclusions \\
\hline $\begin{array}{c}\text { Pedregal\&Oz- } \\
\text { caglar-Toulouse } \\
2011,655-660 \\
\end{array}$ & $\begin{array}{l}\text { Fait Trade phenomena in } \\
\text { France }\end{array}$ & $\begin{array}{l}\text { The lack of access to information and financial re- } \\
\text { sources can explain consumers' refusal to purchase } \\
\text { fair trade products }\end{array}$ \\
\hline $\begin{array}{c}\text { Andorfer\& Liebe } \\
2012,415-435\end{array}$ & $\begin{array}{c}\text { Current state of research } \\
\text { on individual consumption } \\
\text { of Fair Trade in the USA } \\
\text { and UK }\end{array}$ & $\begin{array}{l}\text { Compared to other fields of research on ethical de- } \\
\text { cision making, scholars are only just beginning to } \\
\text { understand and explain individual FT consumption. }\end{array}$ \\
\hline $\begin{array}{c}\text { Raynolds } 2012, \\
276-287\end{array}$ & $\begin{array}{l}\text { Theoretical and empirical } \\
\text { parameters of social regu- } \\
\text { lation in global food mar- } \\
\text { kets, focusing on the rap- } \\
\text { idly expanding Fair Trade } \\
\text { initiative }\end{array}$ & $\begin{array}{c}\text { Fair Trade success deepens competition and buyer } \\
\text { control and erodes peasant base. Growth in new } \\
\text { areas creates opportunities for working with labor } \\
\text { organizations. }\end{array}$ \\
\hline $\begin{array}{l}\text { Yar } \\
\text { \&Mupa } \\
\text { Liu } 20\end{array}$ & $\begin{array}{r}\begin{array}{r}\text { Consumer } \\
\text { pay for fair } \\
\text { Chinese }\end{array} \\
\end{array}$ & $\begin{array}{r}\text { Results show that on averag } \\
\text { ing to pay } 22 \% \text { more for a } \\
\text { Trade coffee compared wi }\end{array}$ \\
\hline $\begin{array}{l}\text { Shahzad \&Sillan- } \\
\text { pää 2013, 29-31 }\end{array}$ & $\begin{array}{c}\text { The role of fair trade in } \\
\text { developing corporate so- } \\
\text { cial responsibility }\end{array}$ & $\begin{array}{l}\text { Fair trade firms give eq } \\
\text { social, and environ }\end{array}$ \\
\hline $\begin{array}{l}\text { Doherty, Davies } \\
\text { \&Tranchell 2013, } \\
\text { 161-189 }\end{array}$ & $\begin{array}{l}\text { The discourse surrounding } \\
\text { Fair Trade mainstreaming, } \\
\text { and discusses the poten- } \\
\text { tial avenues for the future } \\
\text { of the social movement }\end{array}$ & $\begin{array}{l}\text { The paper highlights a number of benefits of main- } \\
\text { streaming, not least the continued growth of the } \\
\text { global Fair Trade market. However, the paper also } \\
\text { highlights the negative consequences of main- } \\
\text { streaming on the long-term viability of Fair Trade as } \\
\text { a credible ethical standard. }\end{array}$ \\
\hline $\begin{array}{l}\text { Stratton \& Wer- } \\
\text { ner 2013, } \\
363-374\end{array}$ & $\begin{array}{l}\text { In-store field study: con- } \\
\text { sumers purchase behavior } \\
\text { of Fair Trade-labeled cof- } \\
\text { fee in a privately owned } \\
\text { coffee shop }\end{array}$ & $\begin{array}{l}\text { Implications for the us } \\
\text { tisements and consum } \\
\text { labels such as Fai }\end{array}$ \\
\hline $\begin{array}{c}\text { Forno\& Graziano } \\
2014,139-157\end{array}$ & $\begin{array}{l}\text { Social mo } \\
\text { current } \mathrm{e}\end{array}$ & $\begin{array}{l}\text { Description of analytical framework which will com- } \\
\text { bine social movements and political consumerism } \\
\text { theories by focusing on two basic dimensions: con- } \\
\text { sumer culture and organizational resources. }\end{array}$ \\
\hline $\begin{array}{c}\text { Dragusanu, Gio- } \\
\text { vannucci\&Nunn, } \\
2014,217-236 .\end{array}$ & $\begin{array}{c}\text { "Economic sense" of Fair } \\
\text { Trade }\end{array}$ & $\begin{array}{c}\text { Critical overview of the economic theory behind } \\
\text { Fair Trade, describing the potential benefits and } \\
\text { potential pitfalls }\end{array}$ \\
\hline Jaffee 2014 & $\begin{array}{r}\text { Benefits o } \\
\mathrm{pr}\end{array}$ & $\begin{array}{l}\text { Actual effect of Fair Trade for coffee farmers in } \\
\text { Mexico }\end{array}$ \\
\hline $\begin{array}{c}\text { Ladhari\&Tchetgna } \\
2015,469-477\end{array}$ & $\begin{array}{l}\text { The study investigates the } \\
\text { motives underlying the } \\
\text { consumption of Fair Trade } \\
\text { (FT) products }\end{array}$ & $\begin{array}{l}3 \text { types of personal values are important: self-di- } \\
\text { rected, equality and social justice, and power and } \\
\text { social status. Also Fair Trade advocates are predis- } \\
\text { posed toward equality and social justice values. }\end{array}$ \\
\hline $\begin{array}{l}\text { Child 2015, } \\
601-618\end{array}$ & $\begin{array}{c}\text { Comparison of Fair Trade } \\
\text { and Socially Responsible } \\
\text { Investments }\end{array}$ & $\begin{array}{l}\text { Three hypotheses: the relation motivations hypoth- } \\
\text { esis, the material interests hypothesis, and the or- } \\
\text { ganization of credibility hypothesis. }\end{array}$ \\
\hline
\end{tabular}




\begin{tabular}{|c|c|c|}
\hline Reference & Subject & Conclusions \\
\hline $\begin{array}{l}\text { Bieler 2016, } \\
\quad 31-41\end{array}$ & $\begin{array}{l}\text { The role of TNC in Free } \\
\text { Trade and Fair Trade }\end{array}$ & $\begin{array}{l}\text { In the long-term the way production itself is orga- } \\
\text { nized, needs to be transformed (different trade ar- } \\
\text { rangements, challenging more fundamentally the } \\
\text { capitalist social relations of production). }\end{array}$ \\
\hline $\begin{array}{l}\text { Chatzidakis, } \\
\text { Kasta- } \\
\text { nakis\&Stathopou- } \\
\text { lou 2016,95-109 }\end{array}$ & $\begin{array}{l}\text { Socio-Cognitive Determi- } \\
\text { nants of Consumers' Sup- } \\
\text { port for the Fair Trade } \\
\text { Movement }\end{array}$ & $\begin{array}{l}\text { The findings suggest that the psychological pro- } \\
\text { cesses underlying fair-trade consumerism are in- } \\
\text { herently more complex than assumed in previous } \\
\text { research. }\end{array}$ \\
\hline $\begin{array}{l}\text { Bailey, Bush, } \\
\text { Oosterveer\&La- } \\
\text { rastiti 2016, 59-68 }\end{array}$ & $\begin{array}{l}\text { The role of middlemen in } \\
\text { Fair Trade USA fishery: } \\
\text { yellowfin tuna from Indo- } \\
\text { nesia }\end{array}$ & $\begin{array}{c}\text { Introduction of Fair Trade has facilitated a rapid re- } \\
\text { organization of value chain structure in the fishery } \\
\text { with notable impacts on fisher perceptions of the } \\
\text { resource and the market }\end{array}$ \\
\hline $\begin{array}{l}\text { Mora- } \\
\text { včíková\&Gregová } \\
\text { 2016, } 340\end{array}$ & $\begin{array}{l}\text { Fair Trade as a tool of Cor- } \\
\text { porate Social Responsibil- } \\
\text { ity }\end{array}$ & $\begin{array}{c}\text { Fair Trade connects developed countries and social } \\
\text { changes are needed most. This is a manifestation of } \\
\text { humanity that helps producers to escape acute } \\
\text { poverty and lead dignified lives. }\end{array}$ \\
\hline $\begin{array}{l}\text { Burnett 2017, } \\
\quad 28-29\end{array}$ & $\begin{array}{l}\text { New Perspectives on the } \\
\text { Fair Trade and Food Sov- } \\
\text { ereignty Movement Strat- } \\
\text { egies to Challenge Inter- } \\
\text { national Trade Govern- } \\
\text { ance }\end{array}$ & $\begin{array}{l}\text { Both movements' strategies are necessary for } \\
\text { changing the international agricultural trade re- } \\
\text { gime, and neither alone is sufficient. }\end{array}$ \\
\hline $\begin{array}{l}\text { O'Connor, Sims \& } \\
\text { White 2017, } \\
\text { 105-112 }\end{array}$ & $\begin{array}{c}\text { Standard Theory of } \\
\text { Planned Behaviour (TPB) } \\
\text { v. attitude to purchase fair } \\
\text { trade foods }\end{array}$ & $\begin{array}{c}\text { First, the reliability of the extended TPB measures } \\
\text { was confirmed via confirmatory factor analysis. } \\
\text { Second, a proposed model predicting people's Fair } \\
\text { Trade purchasing behaviour showed a good fit via } \\
\text { structural equation modelling. }\end{array}$ \\
\hline $\begin{array}{l}\text { Miller 2017, } \\
\text { 249-269 }\end{array}$ & $\begin{array}{l}\text { Issue of trade within the } \\
\text { broader literature on in- } \\
\text { ternational and global jus- } \\
\text { tice }\end{array}$ & $\begin{array}{l}\text { Eight different conceptions of 'fair trade' and the } \\
\text { principles that lie behind them. }\end{array}$ \\
\hline $\begin{array}{l}\text { Goff } 2018 \\
521-543\end{array}$ & $\begin{array}{l}\text { Fair trade: global prob- } \\
\text { lems and individual re- } \\
\text { sponsibilities }\end{array}$ & $\begin{array}{c}\text { Consumers have duties of fairness that are specific } \\
\text { to their roles as participants in global trade, given } \\
\text { that their trading partners have unmet claims un- } \\
\text { der present non-ideal conditions } \\
\end{array}$ \\
\hline $\begin{array}{l}\text { Rössel\& Schenk } \\
\text { 2018, 266-284 }\end{array}$ & $\begin{array}{l}\text { Political consumption } v \text {. } \\
\text { activism for the Fair Trade }\end{array}$ & $\begin{array}{c}\text { Political consumption is not only an academic field } \\
\text { of research, but an increasingly widespread at- } \\
\text { tempt to influence corporations and politicians by } \\
\text { market choices }\end{array}$ \\
\hline $\begin{array}{l}\text { Naylor 2018, } \\
1027-1046\end{array}$ & $\begin{array}{c}\text { Literature on diverse and } \\
\text { community economies to } \\
\text { examine Fair Trade ex- } \\
\text { changes - example of } \\
\text { Mexico } \\
\end{array}$ & $\begin{array}{c}\text { Explanations of Fair Trade as "alternative" and mul- } \\
\text { tiplying of our understanding of what fair trade is. } \\
\text { Utilizing data collected in Chiapas, Mexico with two } \\
\text { coffee producing cooperatives and their U.S.-based } \\
\text { partner roasters. }\end{array}$ \\
\hline Nunn 2019 & $\begin{array}{l}\text { Causes and consequences } \\
\text { of Fair Trade certification }\end{array}$ & $\begin{array}{c}\text { Reflections on the impressive growth of Fair Trade- } \\
\text { certified imports over the past two decades }\end{array}$ \\
\hline $\begin{array}{l}\text { Wang \& Chen } \\
\text { 2019, 66-72 }\end{array}$ & $\begin{array}{l}\text { Effects of perceived jus- } \\
\text { tice of Fair Trade organi- } \\
\text { zations on consumers' }\end{array}$ & $\begin{array}{c}\text { Practical suggestions to Fair Trade related busi- } \\
\text { nesses and organizations, enabling these entities to }\end{array}$ \\
\hline
\end{tabular}




\begin{tabular}{|c|c|c|}
\hline Reference & Subject & Conclusions \\
\hline & $\begin{array}{c}\text { purchase intention to- } \\
\text { ward Fair Trade products }\end{array}$ & $\begin{array}{l}\text { accurately determine directions for the promotion } \\
\text { and marketing communications. }\end{array}$ \\
\hline $\begin{array}{l}\text { Konuk 2019, } \\
141-147\end{array}$ & $\begin{array}{l}\text { Consumers' willingness to } \\
\text { buy and willingness to pay } \\
\text { for fair trade food }\end{array}$ & $\begin{array}{l}\text { Consciousness for fair consumption has the great- } \\
\text { est influence on intentions. }\end{array}$ \\
\hline $\begin{array}{l}\text { Singh \& Singh } \\
2020,1425-1431\end{array}$ & Fair Trade in food sector & $\begin{array}{l}\text { The article tries to elucidate fair trading in food and } \\
\text { agricultural sectors and highlights the recent pro- } \\
\text { gress achieved, with a wider goal of achieving a sus- } \\
\text { tainable development especially in the developing } \\
\text { countries. }\end{array}$ \\
\hline $\begin{array}{l}\text { Bartels, Reinders, } \\
\text { Broersen\& Hen- } \\
\text { driks 2019, 1-25 }\end{array}$ & $\begin{array}{c}\text { Company's fair trade rep- } \\
\text { utation }\end{array}$ & $\begin{array}{c}\text { Skepticism and consumer brand identification play } \\
\text { an important mediating role in the relation among } \\
\text { reputation, fit and consumers' electronic word-of- } \\
\text { mouth intentions. }\end{array}$ \\
\hline $\begin{array}{l}\text { Hur, Lee \&Stoel } \\
2020,186-206\end{array}$ & Fair trade advertising & $\begin{array}{l}\text { This study examined whether and when infor- } \\
\text { mation type is an effective advertising strategy for } \\
\text { fair trade products. Advertisers who promote fair } \\
\text { trade products should consider the combination of } \\
\text { information and visual-written (in)congruency. }\end{array}$ \\
\hline $\begin{array}{c}\text { Zhang \& Liu 2020, } \\
\text { 1205-1227 }\end{array}$ & Fair Trade in China & $\begin{array}{l}\text { Initial investigation into Fair Trade supply chain } \\
\text { management in China, with a focus on its opportu- } \\
\text { nities and challenges. }\end{array}$ \\
\hline
\end{tabular}

Source: own study.

\section{MATERIAL AND METHODS}

In the face of the processes mentioned in the Introduction, ideas of responsibility and justice occur more and more often, particularly in the international context.

The aims of this paper are as follows: to describe how the Fair Trade movement supports the achievement of The Sustainable Development Goals (SDGs), also using A Theory of Change, to analyze the Trade Fair phenomenon in the global scale, in the V4 countries and make a comparison with selected EU countries as well as an attempt to develop recommendations for the Visegrad Group countries in terms of the development of Fair Trade.

The research methods applied in the article are: studying the literature of the subject (scientific articles, books), analysis of source texts(dedicated websites, reports), the descriptive method based on the literature studiesand deductive reasoning- based on the observational method combined with a case study of 4 selected countries belonging to the Visegrad Group.

Available statistical data (annual reports) of organizations which deal with the above subjects were used. In addition, to acquire relevant data, the author of the paper established cooperation with entities operating in Fair Trade in the analyzed V4 countries - Fairtrade Česko and Slovensko, Hungarian Tudatos Vásárlók Egyesületeand and Fundacja "Koalicja Sprawiedliwego Handlu" - Fairtrade Polska.Through the author's individual contacts, it was possible to gain unique, very difficult to obtain statistical data that was used in this article. It is worth emphasizing that some of this data is not published anywhere and collecting them in one place (as well as scientific study and critical evaluation) is a great added value. 


\section{RESULTS AND DISCUSSION}

\section{Fair Trade and The Sustainable Development Goals}

Fair Trade is one of the movements supporting the implementation of the SDGs. It was decided to prioritize goals and support them. Eight main objectives were selected, which are the organization's most dynamic activities. These are the aims and the description of the implemented activities (Fairtrade International, 2020b).

Goal 1: to end poverty in all its forms everywhere

This goal is central to the Fair Trade's mission. All of operation activities stems from this overarching goal as they seek to ensure that trade enables smallholder farmers and workers to earn a decent living and have a brighter future for themselves and their families.

Goal 2: to end hunger, achieve food security and improved nutrition, and promote sustainable agriculture

Small-scale farmers continue to provide a large percentage of the world's population with food. That means creating robust livelihoods is crucial for achieving this goal. Fair Trade enables more secure and stable incomes for small-scale farmers and supports them in building strong, resilient businesses.

Goal 5: to achieve gender equality and empower all women and girls The United Nations Food and Agriculture Organization (FAO) has identified that overcoming gender inequalities can reduce the number of hungry people in the world by 150 million (FAO, 2020). Fair Trade supports women in equal participation in agriculture, earning better wages and diversification of their income and opportunities.

Goal 8: to promote sustained, inclusive and sustainable economic growth, full and productive employment and decent work for all

In line with the United Nations International Labour Organization (ILO, 2020) Fair Trade promotes better working conditions, supports workers to negotiate for better pay and is striving to achieve living wages for workers on Fair Trade plantations. Their standards prohibit child and forced labour and they work with young people, communities, producer organisations and governments to enable them to tackle the root causes themselves.

Goal 12: to ensure sustainable consumption and production patterns

Fairtrade is the leading ethical label worldwide (Fairtrade International, 2020c). Through their campaigns and advocacy work, they bring together thousands of communities and millions of consumers worldwide to campaign for fairer trade. They are also developing markets in the South, for instance in in India, to enable the growing consumer base to make sustainable lifestyle choices.

Goal 13: to take urgent action to combat climate change and its impacts

Small-scale farmers are already bearing the brunt of a changing climate. Fair Trade works with producer organizations and climate experts to build farmers' resilience to climate shocks and stresses and thus be better equipped to adapt to, and mitigate their own impacts on global warming (Fairtrade International, 2020d). 
Goal 16: to promote Peaceful And Inclusive Societies For Sustainable Development, Provide Access To Justice For All And Build Effective, Accountable And Inclusive Institutions At All Levels

Fairtrade focuses on building democracy from the ground up. Producers are equal owners of Fairtrade. From deciding on how to use their Fairtrade Premium, right up to determining global Fairtrade strategy, producers (including women, men, youth, migrants and people with disabilities) have a strong voice and are empowered to demand accountability of their organizations (Fairtrade International, 2020e).

Goal 17: to strengthen the means of implementation and revitalize the global partnership for sustainable development

Power imbalances in supply chains that favour companies over small-scale farmers in developing countries can be a barrier to implementing the SDGs. Fair Trade works with multiple partners - producer organizations, businesses, trade unions, civil society, governments and other multi-stakeholder bodies (Fairtrade International, 2020f). The Fairtrade Theory of Change can help achieve these goals (Fairtrade International, 2020g). For example:

1. Fairtrade International has developed a Theory of Change for Fairtrade as a part of work to improve the Fairtrade Monitoring, Evaluation and Learning (MEL) system the key to understanding the outcomes and impact of Fairtrade and improving approach.

2. The Theory of Change is a generic theory which MEL staff will use as a guiding framework for the designing of monitoring and research activities. However, by analysing data resulting from these MEL activities, it will be possible to test assumptions underlying the Fairtrade approach (for example, the assumption that strengthened small organizations.)

3. The Theory of Change captures the range of activities Fairtrade does as a system (i.e. its interventions) and relates these logically to desired immediate, mid-term and longterm changes. It thereby provides a framework for identifying appropriate indicators for measuring the results of Fairtrade and progress towards Fairtrade's goals - also connected with the Sustainable Development Goals.

4. The Theory of Change can also improve communication regarding Fairtrade/Fair Trade, both internally and externally, and help ensure there is a common understanding about goals and approaches.

5. The Theory of Change has been used as the basis to review existing indicators used by the Fairtrade system to monitor results and to develop an expanded set of core indicators that more fully reflect the range of themes that are in the Theory of Change.

6. The theory stresses the importance of consumer purchasing decisions (behaviour) the goal is to raise awareness among citizen-consumers of the negative effects of unfair trade, and to enable them to use their purchasing decisions to show their support for small producers and workers in developing countries.

So, as can be seen above' Fairtrade/Fair Trade is closely aligned with the Sustainable Development Goals and together with farmers and workers, civil society, governments and businesses. Specific rules such as "Make trade fair", "Empower small producers and workers", "Foster sustainable livelihoods", "Consumer behavior modeling" help in achieving the goals set by the United Nations and known as the Sustainable Development Goals. 


\section{Fair Trade product trading worldwide}

The evolution of Fair Trade has been observed for over half a century. We can distinguish three Fair Trade concepts that are related to the models of selling products produced by poor farmers (Dragusanu et al., 2014; Moravčíková \& Gregová, 2016):

1. an alternative movement - opposition to globalization,

2. resignation from commodification (commodification),

3. liberalization of access to markets of rich countries - availability of goods from countries of the poor South.

Fair Trade products are sold through two distribution channels. The first is the traditional way through an integrated supply chain in which Fair Trade products (craft products, food, etc.) are manufactured, imported and distributed by certified FT organizations that participate in this process, e.g. WFTO members - World Fair Trade Organization (2020) or EFTA - European Fair Trade Association (2020). The second method uses a product certification system in which goods that meet the standards are marked for identification by retail customers.

According to the latest report "Choosing a fairer future through trade 2018-2019", prepared by the International Trade Fair organization, consumers in over 158 economically developed countries spent about EUR 9.8 billion on Fair Trade products (Fairtrade International, 2020h). It means a fivefold increase compared to a decade ago. In 2018, in 73 countries of the world there were already over 1.7 million of small producers and farmers operating in the Fair Trade model, and within so-called social premiums they obtained about EUR 176.5 million (TOP 7 products: coffee, cocoa, bananas, sugar, flowers, tea, cotton). Figure 1 presents changes in the sales of Fair Trade products worldwide in the years 2004-2018.

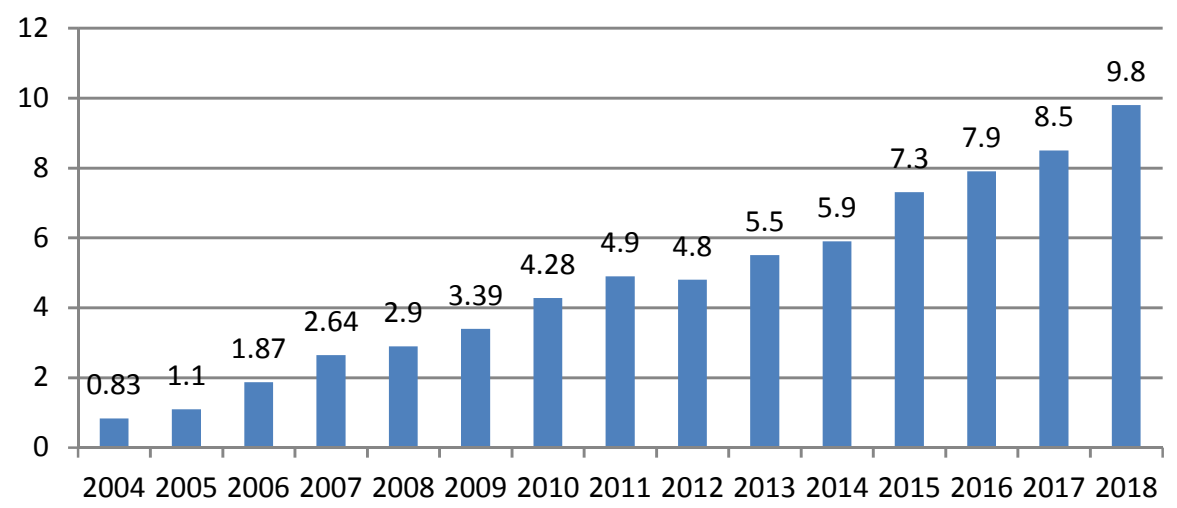

Figure 1. Sales of Fair Trade products worldwide, years 2004-2018, billions of EUR Source: own calculations based on Fairtrade International Annual Reports (Fairtrade,2020).

Trade in Fair Trade goods around the world from 2004 to the end of 2018 was more than eleven times higher. Currently, over 1.7 million families of small producers and farmers from 73 countries are members of 1,707 producer organizations. It is worth emphasizing that we have over 35,000 types of goods worldwide covered by Fair Trade rules. 


\section{Fair Trade product trading in the V4 countries}

In the V4 countries that have formed a political relationship since the political transformation in the early 1990s and based on cooperation (e.g. joint accession to the European structures in 2004), the phenomenon of Fair Trade develops unevenly. The Czech market is the most developed Fair Trade market in the Visegrad Group region. A rise in sales of Fairtrade products in these countries is driven by cafes, gas stations and supermarkets. However, the main factor is an increase in the product range in large retail chains.

Fairtrade Czech Republic and Slovakia is a non-governmental non-profit organization that brings together organizations and individuals. They have been operating in the Czech Republic since 2004, originally under the name Fair Trade Association, which was later renamed Fairtrade Czech Republic and Slovakia. They have been operating in Slovakia since 2014. They are part of Fairtrade International, a full member of the World Fair Trade Organization (WFTO) and since 2010 they have been a member of the Czech Forum for Development Cooperation (FoRS) in the Czech Republic (Fairtrade Cesko, 2020).

If we analyze the development of the Fair Trade phenomenon in Poland, it should be noted that the informal Fair Trade Coalition was founded on March 16, 2009 as an initiative of several small businesses and NGOs. On September 13, 2013, the Foundation was registered in Krakow and on January 15, 2016 the Foundation changed its name to the Fair Trade Coalition Foundation - Fairtrade Polska because they received the status of a public benefit organization. Since April 2015, the Foundation has represented Fairtrade International in Poland, the owner of the Fairtrade mark placed on certified Fair Trade products. Fairtrade Deutschland provides substantive support (Fairtrade Polska, 2020a).

In Hungary, there is an organization called Tudatos Vásárlók Egyesülete (Association of Conscious Consumers). The aim of the Association of Conscious Consumers is to support and strengthen sustainable consumption, ethical (environmentally and socially responsible) consumption and corporate operations, the sustainability of markets, and the knowledge about the rights and obligations of consumers in Hungary. This association has been promoting ethical, environmental and socially conscious consumption and lifestyle choices since 2001 . The organization has been active (local foods fairs, marketing campaigns, lessons to public and professional audience, eco-map, research, books, magazines and other informational materials). The Conscious Consumers Association (2020) published its first report in 2017, which calculated the value of informed decisions of Hungarian consumers.

As it was mentioned earlier, in the Czech Republic the main factor is the increase in the product range in large retail chains, and sales grows in the case of coffee and cocoa. What is interesting, in a large part it is coffee at Benzina stations owned by the Polish state-owned company PKN Orlen. Also in Slovakia, the largest increases have been recorded as regards the sale of coffee and cocoa.

In Poland, the main factor is the dynamic increase in the number of Fairtrade certified products offered by large retail chains. This coincides with the development of the "Fair Trade Friendly Communities" campaign. There is a growing public awareness about the consequences of unfair international trade and the conditions prevailing in agriculture and processing in the countries of the global South, climate change or harmful plastic production. PKN Orlen is the largest seller of Fairtrade products in Poland, which in 2008 intro- 
duced Fairtrade-certified coffee at all its gas stations. Retail chains come second. Important players are also online and stationary stores with organic products (both chains and independent sellers). Polish companies producing for domestic and foreign brands are expressing an increasing interest in Fairtrade certification, especially in the case of sweets.

In the case of Hungary, the rise in the value of the Hungarian market can also be observed. The reason for this was the introduction of Fairtrade coffee for sale at ÖMV gas stations in mid-2016. Another growth factor was an increase in Fairtrade's offer among large retailers.

The so-called initiative of the Fair Trade Towns campaign is worth a mention. Formal guidelines have been produced jointly by several Fairtrade labelling initiatives. To be awarded Fair Trade status, an area must meet five criteria: local council passes a resolution supporting Fair Trade, agrees to serve Fair Trade tea and coffee at its meetings and in its offices and canteens, a range of (at least two) Fair Trade products is readily available in the area's shops and local cafes/catering establishments, target for number of retail outlets, target for number of catering outlets and Fair Trade products are used by a number of local work places (estate agents, hairdressers, etc.) and community organizations (churches, schools, etc.). A local Fair Trade steering group is convened to ensure continued commitment to its Fair Trade Town status. It is worth comparing the number of such cities and areas in Western European countries and in the analysed V4 countries to realize at what stage of development the Fair Trade phenomenon is in our part of Europe. This comparison can be found in the table 2 below.

Table 2. Fair Trade Towns in Europe (selected countries)

\begin{tabular}{|c|c|c|}
\hline Country & Initiative & Number of FT Towns \\
\hline Germany & Kampagne Fairtrade Towns & 648 \\
\hline UK & Fairtrade Towns & 425 \\
\hline Austria & FAIRTRADE-Gemeinden & 207 \\
\hline Belgium (Flanders) & Fair Trade Gemeenten & 200 \\
\hline The Netherlands & Fairtrade Gemeente & 87 \\
\hline Sweden & Fairtrade City & 64 \\
\hline The Republic of Ireland & Fairtrade Towns & 48 \\
\hline Belgium (Wallonia + Brussels) & Communes du commerce équitable & 43 \\
\hline Norway & Fairtrade-Kommune & 37 \\
\hline Luxembourg & Fairtrade Gemeng & 32 \\
\hline France & Territoires de Commerce Equitable & 28 \\
\hline Spain & Ciudad por el Comercio Justo & 19 \\
\hline Finland & Reilunkaupankaupunki & 16 \\
\hline Czech Republic & Fairtradováměsta & 12 \\
\hline Poland & Społeczności Przyjazne dla Sprawie- & 2 \\
\hline
\end{tabular}

Source: (Fair Trade Towns International,2020).

As we can see, the numbers of cities or areas in the V4 countries differ significantly from those in Western Europe (Germany - 648, UK - 425, Austria - 207, Czech Republic 12, Poland -2), and in the case of Slovakia and Hungary there are no such cities at all. 
In the latest report "Choosing a fairer future through trade 2018-2019" prepared by the Fairtrade International there is no data about retail sales of Fair Trade products broken down into individual countries of the world. The report was published in November 2019 whereas in the previous report "Working together for fair and sustainable trade 20172018" we can find this data for 2017. The report includes data for Poland, the Czech Republic and Slovakia together, but unfortunately, there is no data for Hungary. In order to obtain the latest available data the author of this article contacted (in March 2020) directly the entities which deal with the problems of Fair Trade in the analyzed Visegrad countries (V4) - Fairtrade Česko a Slovensko, Hungarian Tudatos Vásárlók Egyesületeand the foundation "Koalicja Sprawiedliwego Handlu" - Fairtrade Polska. Not all of these organizations have full data concerning the Fair Trade product trading since not all are at the same stage of the development of the activity conducted. Table 3 presents the sales of the Fair Trade products in the years 2013-2018 in the V4 countries.

Table 3. The sales of Fair Trade products in the years 2013-2018 in Poland, the Czech Republic, Slovakia and Hungary, millions of EUR

\begin{tabular}{|c|c|c|c|c|c|c|c|}
\hline Country/Year & $\mathbf{2 0 1 3}$ & $\mathbf{2 0 1 4}$ & $\mathbf{2 0 1 5}$ & $\mathbf{2 0 1 6}$ & $\mathbf{2 0 1 7}$ & $\mathbf{2 0 1 8}$ & Total \\
\hline Poland & 4.8 & 6.4 & 6.5 & 8.3 & 14.4 & 21.7 & 62.1 \\
\hline Czech Rep. & 6.6 & 7.7 & 7.4 & no data & 16.9 & 45.9 & 84.5 \\
\hline Slovakia & no data & 1.1 & 1.3 & no data & 8.7 & 16.9 & 28.0 \\
\hline Hungary & no data & 0.2 & 0.3 & 1.4 & 11 & $3.2^{*}$ & 16.1 \\
\hline
\end{tabular}

* calculated average value over four years: 2014-2017

Source: own study based on information (via e-mails) received in March 2020 from Fairtrade Česko a Slovensko, Hungarian Tudatos Vásárlók Egyesülete/Association of Conscious Consumers and Fairtrade Polska/FundacjaKoalicja Sprawiedliwego Handlu.

As can be seen in the above table, the leader in the analyzed period was the Czech Republic (EUR 84.5 millions), followed by Poland (EUR 62.1 millions). The sales of Fair Trade products in Slovakia and Hungary were lower in terms of value (EUR 28.0 and EUR 16.1 million, respectively), however, as it has been already mentioned, the data are incomplete. In order to conduct a deeper comparative analysis, the results of the sales of Fair Trade products in the Visegrad Group countries were compared with a few countries in Europe which were the EU members - data for 2017 (Table 4).

What can be seen from the data presented in the table above is that the sales volume of Fair Trade products in the four Visegrad Group countries considerably differ in the achieved value from the results in more economically developed countries such as the UK (2,013), Germany (1,329), France (561) or Sweden (394). To a lesser extent they differ from Spain and Portugal (Fair Trade International reports provide joint data from these two countries) - EUR 35 million. It seems that the reason for this is a shorter tradition of purchasing Fair Trade certified goods and having less household's available income, different purchasing power standard (PPS ${ }^{3}$ and lower average wages. Table 5 below presents a comparison of these countries in terms of PPS, for which sales of FT products in 2017 were previously presented.

\footnotetext{
${ }^{3}$ PPS represents a common currency that eliminates the differences in price levels between countries to allow meaningful volume comparisons of GDP.
} 
Table 4. The sales of Fair Trade products in the years 2017 in the V4 countries and selected EU countries, millions of EUR

\begin{tabular}{|c|c|}
\hline Country/Fair Trade sales & Sales of Fair Trade products \\
\hline UK & 2,013 \\
\hline Germany & 1,329 \\
\hline France & 561 \\
\hline Sweden & 394 \\
\hline Ireland & 342 \\
\hline Austria & 304 \\
\hline Netherlands & 290 \\
\hline Finland & 233 \\
\hline Belgium & 145 \\
\hline Denmark & 134 \\
\hline Italy & 130 \\
\hline Spain and Portugal & 35 \\
\hline Czech Republic & 16.9 \\
\hline Poland & 14.4 \\
\hline Luxemburg & 13 \\
\hline Hungary & 11 \\
\hline Slovakia & 8.7 \\
\hline
\end{tabular}

Source: (Fairtrade International, 2020i).

In fact, as one can see, in the four Visegrad Group countries under analysis, the PPS ratio significantly differs from the value in more developed Western European countries, it is often even nearly twice as low.

\section{CONCLUSIONS}

What can be seen from the data presented in the article the sales volume of Fair Trade products in the four Visegrad Group countries considerably differ in the achieved value from the results in more economically developed countries in Europe.

To increase the sales of Fair Trade products in the V4 countries, they may use best practice, for example from the UK - the European leader in this field. For instance, a very readable and useful Fair Trade guide could be developed: "National Fairtrade Purchasing Guide. Why And Where To Buy Fairtrade For Your Business" (Fairtrade UK, 2020). There we will find a list of wholesalers dealing with the sale of FT products, larger and smaller stores, cafes, sales outlets, the opportunity to take up work in structures supporting the development of the FT phenomenon, all possible contacts and necessary data.

In addition, more international programs should be created along the lines of the example "V4 Cooperation for moving forward fair trade as a socially innovative economic model" - the so called Visegrad Project. It started in 2018 as an international project. Apart from the Fair Trade Coalition Foundation - Fairtrade Polska, NGOs from the Czech Republic, Slovakia and Hungary participate in the project. The goal of the project financed from the International Visegrad Fund is to tighten cooperation for the development of Fairtrade markets in the countries of the Visegrad Group (Fairtrade Polska, 2020b). Four organizations: the Fair Trade Coalition Foundation - Fairtrade Polska, Fairtrade Česko a Slovensko, 
the Slovak organization Nadácia Integra and the Hungarian Association of Conscious Consumers Tudatos Vásárlók Egyesülete joined forces to jointly promote the idea of Fair Trade and Fairtrade certification products and to support shop owners and cafes selling Fairtrade certified products as part of the project. Czech and Polish partners are specialized organizations working to promote the Fairtrade brand. The Association from Hungary represents consumers and the Slovak organization cooperates with Ten Senses Africa - a Kenyan nut processing plant whose mission is to support small farmers under Fair Trade. It would be good to know the effects of this program after two years of its duration.

As the authors of the theory write in the introduction to their study: "Globalization has accelerated the integration of markets, facilitated by improvements in technology, transport and communications. Small producers in developing countries have been largely marginalized from the benefits of international trade. Although they often account for a high proportion of production (depending on the sector and country), they typically lack the necessary skills, resources, information, institutions, access to markets and bargaining power to secure a decent return for their labour. Although there has been renewed interest among national governments and bilateral and multilateral agencies in supporting small-scale production in recent years, this is largely within a political framework which focuses on increasing productivity and does little to address other structural issues outlined above" (Francesconi \& Ruben, 2014).

Having studied the trade of Fair Trade products in the Visegrad countries in this article, in spite of relatively medium Purchasing Power Standard (PPS) positions of the V4 countries the results were obtained which indicate that the value of those indices had no significant influence on the sales of Fair Trade products, and the sales level in the analysed countries considerably differs from other developed EU countries.

It is to be hoped that the proposed recommendations and actions taken in the described countries will bring greater results in the development of the Fair Trade phenomenon in the coming years.

It should be noted that research on the Fair Trade phenomenon in the Visegrad Group countries has some limitations. They are related to the lack of certain statistical data, which the author mentions in the article. There is no uniform methodology for collecting, processing and sharing data in these countries. In the reports of organizations and associations dealing with Fair Trade in the world, these countries very often do not appear at all, which makes it very difficult to conduct research.

My planned future research will be a continuation of my previous interests. In particular, I would like to focus on exploring the practical use of "power of big cities" in the development of direct commercial cooperation with agricultural producers in the countries of the global South, constructing a price model for direct import of Fair Trade products (assuming the elimination of unnecessary intermediaries and shortening the supply chain) and taking attempts to apply my theory of Fair Trade 3.0 on the markets of the V4 countries of the Visegrad Group (study of major cities of the region).

\section{REFERENCES}

Andorfer, V.A., \& Liebe, U. (2012). Research on fair trade consumption-A review. Journal of Business Ethics, 106(4), 415-435. 
Audebrand, L.K., \&Pauchant, T.C. (2009). Can the fair trade movement enrich traditional business ethics? An historical study of its founders in Mexico. Journal of Business Ethics, 87(3),343-353.

Bailey, M., Bush, S., Oosterveer, P., \&Larastiti, L. (2016). Fishers, fair trade, and finding middle ground. Fisheries Research, 182, 59-68.

Bartels, J., Reinders, M.J., Broersen, C. \& Hendriks, S. (2019). Communicating the fair trade message: the roles of reputation and fit. International Journal of Advertising, 39(4), 1-25, DOI: 10.1080/02650487.2019.1662251.

Bezençon V., \&Blili, S. (2009).Fair trade managerial practices: Strategy, organisation and engagement. Journal of Business Ethics, 90(1), 95-113.

Bieler A. (2016). From 'FreeTrade' to 'Fair Trade': Proposals for Joint Labour Demands towards an Alternative Trade Regime. In A. Bieler, R. O'Brien \& K. Pampallis (Eds.), Challenging Corporate Capital: Creating an Alternative to Neo-liberalism (pp. 31-41). Johannesburg, Chris Hani Institute.

Bondy, T.,\& Talwar, V. (2011). Through thick and thin: How fair trade consumers have reacted to the global economic recession. Journal of Business Ethics, 101(3), 365-383.

Burnett K. (2017). Navigating the Land Between Religions: New Perspectives on the Fair Trade and Food Sovereignty Movement Strategies to Challenge International Trade Governance. Retrieved March 21, 2020 fromhttps://uwspace.uwaterloo.ca/bitstream/handle/10012/12456/Burnett_Kimberly.pdf?sequence $=3$.

Chatzidakis A., Kastanakis M.,\&Stathopoulou A. (2016). Socio-cognitive determinants of consumers' support for the fair trade movement. Journal of Business Ethics, 133(1), 95-109.

Child C. (2015). Mainstreaming and its discontents: Fair trade, socially responsible investing, and industry trajectories. Journal of Business Ethics, 130(3), 601-618.

Doherty, B., Davies, I.A.,\&Tranchell, S. (2013). Where now for fair trade? Business History, 55(2), 161-189.

Doran, C.J. (2009). The role of personal values in fair trade consumption. Journal of Business Ethics, 84(4), 549-563.

Dragusanu R., Giovannucci D., \&Nunn N. (2014). The Economics of Fair Trade. Journal of Economic Perspectives, 28(3), 217-236.

European Fair Trade Association. (2020). Retrieved on March 21, 2020 from http://www.europeanfair-trade-association.org.

Eurostat. (2020).Purchasing power standard (PPS) in selected EU countries. Retrieved on March 21, 2020 from https://ec.europa.eu/eurostat/web/products-datasets/-/tec00114.

Fair Trade Towns International. (2020). Retrieved on March 21, 2020 from http://www.fairtradetowns.org.

Fairtrade Cesko. (2020). Retrieved March 21, 2020 from https://fairtrade-cesko.cz.

Fairtrade International. (2020a).The Sustainable Development Goals. Retrieved on March 21, 2020 from https://www.fairtrade.net/issue/sdgs.

Fairtrade International. (2020b).Fairtrade Sustainable Trade Development. Retrieved on March 21, 2020 from https://files.fairtrade.net/publications/2020-01-Updated_FairtradeSustainableTradeDevelopment_EN.pdf.

Fairtrade International. (2020c).How Fairtrade Works. Retrieved on March 21, 2020 from https://www.fairtrade.net/about/how-fairtrade-works.

Fairtrade International. (2020d).Climate change. Retrieved on March 22, 2020 from https://www.fairtrade.net/issue/climate-change. 
Fairtrade International. (2020e).Peace, Justice and Strong Institutions. Retrieved on March 23, 2020 from https://www.fairtrade.net/issue/sdg16.

Fairtrade International. (2020f).Partnerships for the Goals. Retrieved on March 24, 2020 from https://www.fairtrade.net/issue/sdg17.

Fairtrade International. (2020g).Fairtrade Theory of Change. Retrieved on March 11, 2020 from https://www.fairtrade.net/library/fairtrade-theory-of-change.

Fairtrade International. (2020h).Annual Report: Choosing a fairer future through trade. Retrieved March 18, 2020 from https://www.fairtrade.net/library/2018-19-annual-report-choosing-afairer-future-through-trade.

Fairtrade International. (2020i).Report: Working together for fair and sustainable trade 20172018.Retrieved March 18, 2020 from https://www.fairtrade.net/library/2017-18-annual-report-working-together-for-fair-and-sustainable-trade.

Fairtrade Polska. (2020a). O nas - fundacja. Retrieved on March 11, 2020 from https://www.fairtrade.org.pl/o-nas/fundacja/.

Fairtrade Polska (2020b). Fairtrade Polska partnerem w projekcie na rzecz rozwoju Fair Trade $w$ Grupie Wyszehradzkiej. Retrieved on March 18, 2020 from https://www.fairtrade.org.pl/aktualnosc/fairtrade-polska-partnerem-w-projekcie-na-rzecz-rozwoju-fairtrade-w-grupiewyszehradzkiej/

Fairtrade UK (2020).National Fairtrade Purchasing Guide 2019. Retrieved on March 17, 2020 from https://www.fairtrade.org.uk.

Fairtrade (2020). Fairtrade International Annual Reports, years 2003/2004-2018/2019. Retrieved March 21, 2020 from https://www.fairtrade.net/library/2018-19-annual-report-choosing-afairer-future-through-trade/.

Food and Agriculture Organization (2020). Women hold the key to building a world free from hunger and poverty. Retrieved on March 16, 2020 from http://www.fao.org/news/story/en/item/460267/icode/.

Forno F.,\&Graziano P.R. (2014). Sustainable community movement organisations. Journal of Consumer Culture, 14(2),139-157.

Francesconi, G.N.,\& Ruben, R. (2014). Fair Trade's theory of change: an evaluation based on the cooperative life cycle framework and mixed methods. Journal of Development Effectiveness, 6(3), 268-283.

Goff, S.C. (2018). Fair trade: global problems and individual responsibilities. Critical Review of International Social and Political Philosophy, 21(4), 521-543.

Goworek, H. (2011). Social and environmental sustainability in the clothing industry: a case study of a fair trade retailer. Social Responsibility Journal, 7(1), 74-86.

Hur, S., Lee, J. E., \& Stoel, L. (2020). Fair trade advertising: Influences of information type and emotional appeal congruency. Journal of Marketing Communications, 26(2), 186-206.

International Labour Organization. (2020).Introduction to international labour standards. Retrieved on March 25 from https://www.ilo.org/global/standards/introduction-to-international-labourstandards/the-benefits-of-international-labour-standards/lang--en/index.htm.

Jaffee, D. (2014). Brewing justice: Fair trade coffee, sustainability, and survival. Univ of California Press.

Jaffee, D., \& Howard, P.H. (2010). Corporate cooptation of organic and fair trade standards. Agriculture and human values, 27(4), 387-399. 
Konuk, F.A. (2019). Consumers' willingness to buy and willingness to pay for fair trade food: The influence of consciousness for fair consumption, environmental concern, trust and innovativeness. Food Research International, 120, 141-147.

Ladhari, R., \& Tchetgna, N.M. (2015). The influence of personal values on Fair Trade consumption. Journal of Cleaner Production, 87, 469-477.

Miller, D. (2017). Fair trade: what does it mean and why does it matter? Journal of Moral Philosophy, 14(3), 249-269.

Moravčíková, K., \& Gregová, E. (2016). Fair Trade as a tool of Corporate Social Responsibility. CBU International Conference on Innovations in Science and Education, Praha, 4, 340-345.

Naylor, L. (2018). Fair trade coffee exchanges and community economies. Environment and Planning A: Economy and Space, 50(5), 1027-1046.

Nicholls, A. (2010). Fair trade: Towards an economics of virtue. Journal of Business Ethics, 92(2), 241255.

Nunn, N. (2019). The Economics of Fair Trade. NBER Reporter, 2, 27.

O'Connor, E.L., Sims, L. \& White, K.M. (2017). Ethical food choices: Examining people's Fair Trade purchasing decisions. Food Quality and Preference, 60, 105-112.

Pedregal, V.D.,\&Ozcaglar-Toulouse, N. (2011). Why does not everybody purchase fair trade products? The question of the fairness of fair trade products' consumption for consumers. International Journal of Consumer Studies, 35(6), 655-660.

Raynolds, L.T. (2012). Fair Trade: Social regulation in global food markets. Journal of Rural Studies, 28(3), 276-287.

Rössel, J., \& Schenk, P.H. (2018). How political is political consumption? The case of activism for the Global South and Fair Trade. Social Problems, 65(2), 266-284.

Shahzad K,.\&Sillanpää I. (2013).The role of fair trade in developing corporate social responsibility: An empirical examination based on multiple cases. Proceedings of 2013 International Conference on Technology Innovation and Industrial Management, 29-31 May 2013, Phuket, Thailand, 29-31.

Singh, D., \& Singh, J.P. (2020). Fair Trade in Food Sector: A Feasible Way To Achieve Sustainable Development. Studies in Indian Place Names, 40(1), 1425-1431.

Stratton, J.P., \& Werner, M.J. (2013). Consumer behavior analysis of fair trade coffee: Evidence from field research. The Psychological Record, 63(2), 363-374.

The Conscious Consumers Association. (2020). Retrieved on March 11, 2020 from https://tudatosvasarlo.hu.

The Fairtrade Foundation. (2020). Retrieved March 21, 2020 from https://www.fairtrade.org.uk/ /media/FairtradeUK/What\%20is\%20Fairtrade/Documents/National\%20Purchasing\%20Guide\%202019.pdf.

United Nations. (2020).Sustainable Development Goals.Retrieved March 11, 2020 fromhttps://sustainabledevelopment.un.org/?menu=1300.

Wang, E.S.T., \& Chen, Y.C. (2019). Effects of perceived justice of fair trade organizations on consumers' purchase intention toward fair trade products. Journal of Retailing and Consumer Services, $50,66-72$.

Wilson, B.R. (2010). Indebted to fair trade? Coffee and crisis in Nicaragua. Geoforum, 41(1), 84-92.

World Fair Trade Organization. (2020). Retrieved March 21, 2020 from https://wfto.com.

Yang, S.H., Hu, W., Mupandawana, M., \& Liu, Y. (2012). Consumer willingness to pay for fair trade coffee: a Chinese case study. Journal of Agricultural and Applied Economics, 44(1), 21-34. 
Zhang, K., \& Liu, Z. (2020). An Investigation on Fair Trade Business: Opportunities and Challenges. In M. Khosrow-Pour (Ed.), Supply Chain and Logistics Management: Concepts, Methodologies, Tools, and Applications(pp. 1205-1227).Hershey, Pennsylvania: IGI Global, DOI: 10.4018/978-17998-0945-6.ch057.

\section{Author}

\section{Wojciech Zysk}

Associate Professor (Prof. UEK) in the Department of International Trade of Cracow University of Economics (Poland). Habilitated doctor of economics and finance (2013), PhD in economics (2003). He is the author and co-author of several books and over 90 scientific articles. His research interests include FDI, fair trade, SRI, CSR, international entrepreneurship, e-commerce, foreign trade, European business.

Correspondence to: Prof. Wojciech Zysk PhD, Cracow University of Economics, Department of International Trade, ul. Rakowicka 27, 31-510 Kraków, Poland, e-mail: zyskw@uek.krakow.pl ORCID (i) http://orcid.org/0000-0003-2231-7941

\section{Acknowledgements and Financial Disclosure}

The publication was co-financed from funds allocated to Cracow University of Economics as the part of a grant for maintaining research potential.

\section{Copyright and License}

This article is published under the terms of the Creative Commons

Attribution - NoDerivs (CC BY-ND 4.0) License

http://creativecommons.org/licenses/by-nd/4.0/

Published by Cracow University of Economics - Krakow, Poland

Ministry of Science and Higher Education Republic of Poland
The journal is co-financed in the years $2019-2020$ by the Ministry of Science and Higher Education of the Republic of Poland in the framework of ministerial programme "Support for Scientific Journals" (WCN) on the basis of contract no. 238/WCN/2019/1 concluded on 15 August 2019. 